\title{
Zasady przygotowywania list słownych dla języka polskiego w audiologii - wybrane zagadnienia lingwistyczne $i$ akustyczne
}

\section{Essentials of the preparation of word lists in the Polish language in audiology - selected linguistic and acoustic issues}

\author{
Anna Skoczylas ${ }^{1}$, Zdzisław Marek Kurkowski²,3, Wojciech Będziński³ \\ ${ }^{1}$ Instytut Fizjologii i Patologii Słuchu, Światowe Centrum Słuchu, Klinika Rehabilitacji, Warszawa/Kajetany \\ ${ }^{2}$ Uniwersytet Marii Curie-Skłodowskiej, Zakład Logopedii i Językoznawstwa Stosowanego, Lublin \\ ${ }^{3}$ Instytut Fizjologii i Patologii Słuchu, Światowe Centrum Słuchu, Klinika Audiologii i Foniatrii, \\ Warszawa/Kajetany
}

Adres autora: Anna Skoczylas, Światowe Centrum Słuchu, ul. Mokra 17, Kajetany, 05-830 Nadarzyn, e-mail: a.skoczylas@ifps.org.pl

\section{Streszczenie}

Audiometria mowy, zwana też audiometrią słowną, jest narzędziem szeroko stosowanym w audiologii. Opracowanie odpowiedniego testu w taki sposób, by był on przydatny w praktyce klinicznej, jest złożonym, długotrwałym procesem wymagającym znacznego nakładu pracy i kooperacji specjalistów z różnych dziedzin. Autorzy niniejszej publikacji koncentrują się na aspektach lingwistycznych związanych z doborem materiału werbalnego, który mógłby zostać użyty w audiometrii słownej.

Słowa kluczowe: audiometria mowy • listy słowne • wrażliwość na mowę

Abstract

Speech audiometry is a valuable tool in audiology. The development and validation of this test designed for clinical purposes is a long and complicated process that requires a lot of work and cooperation of specialists from different fields. Authors of this paper focus on aspects connected with verbal material in the development of word recognition testing.

Key words: speech audiometry • word lists $\bullet$ speech sensitivity

\section{Wprowadzenie}

Terminy 'audiometria słowna' lub 'audiometria mowy' (ang. speech audiometry) oznaczają te rodzaje badań słuchu, w których mowa używana jest jako bodziec. Badania te, będące uzupełnieniem audiometrii tonalnej, są szeroko stosowane w diagnostyce audiologicznej, choć często bywają niedoceniane w praktyce klinicznej. Lekarze audiolodzy podczas diagnostyki najczęściej opierają się na wynikach audiometrii tonalnej, wykonywanej z wykorzystaniem tonów czystych. Pozwala ona wyznaczyć próg czułości słuchu, jednak wyższy próg czułości słuchu, oznaczający większy ubytek słuchu, nie zawsze oznacza proporcjonalnie gorsze rozumienie mowy. Audiometria słowna pozwala ocenić nie tylko możliwości przenoszenia dźwięku przez układ słuchowy, lecz także przetwarzanie informacji werbalnych na wyższych piętrach tego układu.
Dzięki wynikom otrzymanym w tym badaniu znacznie trafniej niż przy audiometrii tonalnej udaje się zidentyfikować pacjentów, którzy mają trudności z radzeniem sobie $\mathrm{z}$ informacjami podawanymi drogą słuchową. $\mathrm{Z}$ tego powodu uznaje się, że badanie audiologiczne pozbawione pomiaru możliwości pacjenta dotyczących odbioru i „obróbki” mowy jest niepełne. W literaturze poświęconej temu zagadnieniu wskazuje się, że audiometria słowna i audiometria tonalna powinny być traktowane jako wzajemnie się uzupełniające i należy rozpatrywać je łącznie [1-3]. W Polsce opracowano wiele testów audiometrycznych, w których bodźcem jest mowa. W praktyce klinicznej najbardziej poszukiwane są badania, których wykonanie zajmuje niewiele czasu, jednak jedynie prawidłowo opracowane i zwalidowane narzędzie cechuje się dużą przydatnością kliniczną. Przygotowanie audiometrii słownej w taki sposób, by jej wykonanie zabierało niewiele czasu, a wyniki 
Tabela 1. Chronologiczny wykaz testów słownych wykorzystywanych w audiometrii mowy w Polsce według dostępnej literatury, za [10]

Table 1. Chronological list of speech tests used in speech audiometry in Poland, according to the available literature, after [10]

\begin{tabular}{|c|c|c|}
\hline $\begin{array}{l}\text { Rok utworzenia testu } \\
\text { słownego }\end{array}$ & Rodzaj testu słownego & Nazwiska autorów \\
\hline 1953 & Listy słów jednosylabowych & $\begin{array}{l}\text { A. Zakrzewski, W. Suwalski, } \\
\text { F. Antkowski, J. Suwalski }\end{array}$ \\
\hline 1957 & Listy wyrazów o różnej liczbie sylab & J. Jassem, R. Piela, M. Steffen \\
\hline 1961 & $\begin{array}{l}\text { Lista słów jednosylabowych i dwusylabowych (bez zrównoważenia } \\
\text { fonetycznego) }\end{array}$ & $\begin{array}{l}\text { J. Taniewski, R. Kugler, } \\
\text { Z. Wysocki }\end{array}$ \\
\hline 1963 & $\begin{array}{l}\text { Test zdaniowy dla dorosłych i dzieci, test liczbowy i test } \\
\text { logatomowy }\end{array}$ & S. Iwankiewicz, B. Siciński \\
\hline 1963 & Listy słów jednosylabowych dla dzieci & $\begin{array}{l}\text { Z. Szmeja, A. Pruszewicz, } \\
\text { K. Dukiewicz }\end{array}$ \\
\hline 1964 & Testy słowne dla dzieci w wieku przedszkolnym i szkolnym & R. Kugler \\
\hline lata 70. XX w. & $\begin{array}{l}\text { Badania słuchu szeptem u dzieci z uwzględnieniem wieku rozwojowego } \\
\text { badanych }\end{array}$ & $\begin{array}{l}\text { D. Borkowska-Gaerting, } \\
\text { I. Urbańska, B. Potyrała, } \\
\text { Ł. Sobieszczańska- } \\
\text {-Radoszewska }\end{array}$ \\
\hline 1971 & Listy słów jednosylabowych i dwusylabowych & $\begin{array}{l}\text { A. Zakrzewski, A. Pruszewicz, } \\
\text { H. Kubzdela }\end{array}$ \\
\hline 1993 & Listy NLA-93 - listy wyrazów jednosylabowych i listy liczbowe & $\begin{array}{l}\text { A. Pruszewicz, G. Demenko, } \\
\text { L. Richter, T. Wika }\end{array}$ \\
\hline 1996 & $\begin{array}{l}\text { Testy słowne do badania percepcji mowy u dzieci z wszczepami } \\
\text { ślimakowymi z uwzględnieniem specyfiki języka polskiego (na podstawie } \\
\text { programu TAPS z ośrodka Cochlear z Bazylei) }\end{array}$ & $\begin{array}{l}\text { G. Demenko, L. Richter, } \\
\text { A. Pruszewicz, W. Szyfter, } \\
\text { B. Woźnica }\end{array}$ \\
\hline 2004 & Polskie listy słów dwusylabowych & $\begin{array}{l}\text { R.W. Harris, W.S. Nielson, } \\
\text { D.L. McPherson, H. Skarżyński }\end{array}$ \\
\hline $2009-2015$ & $\begin{array}{l}\text { Polskie testy do badań zrozumiałości mowy dla dzieci, młodzieży } \\
\text { i dorosłych }\end{array}$ & E. Ozimek \\
\hline 2011 & $\begin{array}{l}\text { Polski test słowny i liczbowy: spełnia wymagania polskiej normy } \\
\text { PN-EN ISO 8253-3: } 2005\end{array}$ & G. Demenko, A. Pruszewicz \\
\hline 2013 & $\begin{array}{l}\text { Test rozumienia zdań w szumie HINT (na podstawie protokołu } \\
\text { opracowanego w Department of Human Communication Sciences and } \\
\text { Devices, House Ear Institute (HEI) w Stanach Zjednoczonych) }\end{array}$ & M. Śliwińska-Kowalska \\
\hline
\end{tabular}

były rzetelne, jest długotrwałym procesem wymagającym znacznego nakładu pracy i kooperacji specjalistów z różnych dziedzin, m.in. lekarzy, językoznawców, akustyków, statystyków, informatyków. Autorzy niniejszej publikacji skupili się na różnych aspektach związanych z doborem materiału werbalnego, który mógłby zostać użyty w badaniach, w których bodźcem jest mowa.

\section{Cel zastosowania różnych typów audiometrii słownej}

Audiometria słowna zależnie od materiału zastosowanego w danym teście (np. zdania, sylaby, słowa) może służyć do różnych celów w badaniach klinicznych. Obecnie w diagnostyce audiologicznej najchętniej wykorzystywane są testy zdaniowe i testy zawierające słowa jednosylabowe. Badanie, w którym bodźcem są zdania, jest najbliższe naturalnym sytuacjom komunikacyjnym i pozwala ocenić ogólne funkcjonowanie pacjenta na co dzień, a wykonane dwukrotnie - przed zaopatrzeniem i po zaopatrzeniu w protezę słuchu - pozwala też ocenić efekty korzystania z aparatów lub implantów [4]. Testy wykorzystujące słowa dwusylabowe są używane do wyznaczania progu rozumienia mowy, a rezultaty otrzymane dzięki nim są też wskazówką dotyczącą wrażliwości na mowę (ang. speech sensitivity) i pozwalają dodatkowo ocenić wartość badania audiometrycznego, w którym wyznacza się próg detekcji dźwięku, stosując w tym celu tony czyste [4-6]. Badania wykorzystujące słowa jednosylabowe bądź logatomy pozwalają na ocenę dyskryminacji dźwięków mowy i ukazanie zależności pomiędzy intensywnością bodźca a rezultatem osiąganym przez pacjenta, która służy do oceny klinicznej różnych aspektów niedosłuchu oraz miejsca uszkodzenia drogi słuchowej $[4,7,8]$.

\section{Testy audiometrii słownej stosowane w Polsce}

Przez wiele lat diagnostyka audiologiczna opierała się na subiektywnej ocenie jakości rozmowy z pacjentem i badaniach ankietowych, jednak prace Fletchera i Egana prowadzone w latach 40 . XX w. zainicjowały rozwój testów do badania audiometrią mowy [9].

W Polsce pierwsze testy do badania audiometrią mowy opracowano w latach 50. XX w. Do tej pory powstało wiele takich testów, ponieważ przy ich opracowaniu uwzględniano różne kryteria, zależnie od celu, jakiemu miał służyć opracowywany materiał [10] (tabela 1). 
Tabela 2. Aspekty metodologiczne audiometrii mowy

Table 2. Metodological aspects of speech audiometry

\begin{tabular}{|c|c|c|}
\hline \multicolumn{3}{|c|}{ Materiał lingwistyczny } \\
\hline Rodzaj sygnałów słownych & Charakter zrównoważenia list & Rodzaj testu \\
\hline wyrazy znaczące & fonematyczne & otwarty \\
\hline logatomy & semantyczne & zamknięty \\
\hline jednostki izolowane & strukturalne & \\
\hline sylaby & gramatyczne & \\
\hline wyrazy & akustyczne & \\
\hline \multicolumn{3}{|l|}{ zdania } \\
\hline \multicolumn{3}{|l|}{ mowa ciągła } \\
\hline \multicolumn{3}{|c|}{ Realizacja akustyczna testu } \\
\hline Cechy akustyczne g & & Technika nagrania \\
\hline męski/ kob & & cyfrowa \\
\hline szkolony/ nies & & analogowa \\
\hline \multicolumn{3}{|c|}{ naturalny/ syntetyczny } \\
\hline \multicolumn{3}{|c|}{ Technika badania audiometrycznego } \\
\hline Strategia testu & Sposób prezentacji & Zapis wyników \\
\hline ustalona & przez słuchawki & powtarzanie rozpoznanych sygnałów \\
\hline \multirow[t]{2}{*}{ adaptacyjna } & w wolnym polu & zapisywanie rozpoznanych sygnałów \\
\hline & & wskazywanie rozpoznanych sygnałów \\
\hline \multicolumn{3}{|c|}{ Metoda oceny wyników } \\
\hline Wybór jednostki d & & Sposób oceny \\
\hline fonemy & & subiektywny \\
\hline wyrazy & & obiektywny \\
\hline \multicolumn{3}{|l|}{ zdania } \\
\hline \multicolumn{3}{|c|}{ jednostki kluczowe } \\
\hline mowa ciągt & & \\
\hline
\end{tabular}

Za: Demenko G., Pruszewicz A. Audiometria mowy. W: Pruszewicz A, red. Zarys audiologii klinicznej. Poznań: Wydawnictwa Akademii Medycznej im. Karola Marcinkowskiego; 2000, s. 238.

\section{Aspekty metodologiczne audiometrii mowy}

Aby opracować rzetelne badanie $\mathrm{z}$ wykorzystaniem audiometrii mowy, należy uwzględnić znaczną liczbę czynników zależnych od zastosowanego materiału werbalnego, m.in. (a) w jakich warunkach będzie wykorzystywany, (b) w jaki sposób (c) kogo zamierzamy badać, (d) jakimi cechami powinien się charakteryzować opracowany materiał. Ze względu na to, że niektóre z tych czynników stoją ze sobą w sprzeczności, należy dokonywać wyborów i poszukiwać kompromisów. Najistotniejszym pytaniem, które należy sobie zadać, opracowując badanie audiometrii słownej, jest zatem pytanie o to, czemu ma służyć dany test: ocenie dyskryminacji dźwięków mowy czy ocenie rozumienia mowy i zysków z protez słuchowych. Zarówno nakład pracy, jak i tok postępowania zależą od wyznaczonego celu badania (tabela 2 ).

\section{Materiał werbalny}

Na dobór i opracowanie materiału werbalnego wpłynie cel badania. W audiometrii słownej wykorzystuje się jednostki mowy różnego rodzaju [11]:

a) wyrazy jednosylabowe,

b) logatomy (słowa sztucznie stworzone, nieniosące informacji semantycznej),

c) spondeje (wyrazy dwusylabowe, w których na każdą sylabę przypada identyczny akcent),

d) liczby dwucyfrowe (służą do ustalenia ubytków słuchu dla mowy),

e) zdania,

f) mowę ciągłą (zbliżoną do naturalnej narracji, jednak określoną powtarzalnymi regułami np. jak przy dyktowaniu).

Materiał ten w obrębie wszystkich list i w całym teście powinien być maksymalnie zrównoważony, a w niektórych aspektach wyrównany. Termin 'zrównoważony' oznacza, że zebrany materiał powinien być proporcjonalnym 
odzwierciedleniem wzorca (tu: naturalnego języka), natomiast termin 'wyrównany' oznacza, że cały materiał powinien się wykazywać jednakową intensywnością określonej cechy.

Za materiał werbalny wszechstronnie zrównoważony uznaje się taki, w którym uwzględniono równoważenie semantyczne, akustyczne, gramatyczne, energetyczne, fonematyczne, strukturalne [11].

Równoważenie semantyczne oznacza, że test powinien zawierać słowa najczęściej występujące, ponieważ częstość pojawiania się słowa w danym języku wpływa na „osłuchanie się" i łatwość w jego odbiorze. Przy ocenie częstości występowania słowa $\mathrm{w}$ danym języku przydatnym narzędziem są listy frekwencyjne słów.

Znaczny wpływ na rozumienie danego słowa ma to, jaką część mowy ono stanowi. Krótkie, niesamodzielne części mowy, najczęściej pozbawione własnego akcentu, takie jak np. przyimki, spójniki (np. że, na, do) pomimo dość wysokiej frekwencji w języku są dużo trudniejsze do zrozumienia i powtórzenia niż wielosylabowe rzeczowniki czy czasowniki. Zastosowanie we wszystkich listach słownych jednej części mowy (np. rzeczownika) nie zapewni jeszcze sukcesu, gdyż język polski jest językiem fleksyjnym, co oznacza, że komunikując się, zmieniamy wyraz, dostosowując jego formę do kontekstu, w jakim zostanie użyty. Zastosowanie danej formy fleksyjnej (w Narodowym Korpusie Języka Polskiego nazywany słowoforma) jest zaś decydujące dla frekwencji tego słowa w języku. Na przykład zgodnie $\mathrm{z}$ informacjami zawartymi w bazie danych Narodowego Korpusu Języka Polskiego wskazanymi za pomocą wyszukiwarki PELCRA dwusylabowa słowoforma domu jest częściej używana niż jednosylabowa dom [12]. Zastosowanie tej samej formy fleksyjnej jednej części mowy w całym teście pozwoli na wyrównanie gramatyczne materiału werbalnego.

Przy wybieraniu wyrazów z korpusów tekstowych należy rozważyć, czy w teście zostaną zastosowane słowa z języka mówionego czy pisanego, bowiem każdy z nich ma swoje style. Styl naukowy, urzędowy są na przykład charakterystyczne dla języka pisanego. W obrębie każdego stylu języka pisanego stosowane jest charakterystyczne słownictwo np. powództwo, zrzekać się, które w języku mówionym może nie występować lub występować bardzo rzadko. Sprawia to, że osoba badana $\mathrm{z}$ użyciem tych słów, a posiadająca niezbyt wysoką kompetencję językową, może nie być $\mathrm{z}$ nimi zaznajomiona. Zatem stosując te słowa w badaniu osoby o niskiej kompetencji językowej, zbadamy nie rozumienie, ale dyskryminację poszczególnych dźwięków, ich szeregowanie i poprawność ich mechanicznego odtworzenia, a to z kolei w znacznym stopniu wpłynie na trafność badania. W rozumienie zaangażowane są złożone procesy poznawcze, a rozpoznanie akustycznej formy słowa jest jedynie etapem wstępnym. Język mówiony jest znacznie bardziej przystępny dla przeciętnego odbiorcy i mniej zależny od takich czynników jak inteligencja czy wykształcenie badanego. Wadą baz danych ${ }^{1}$ zawierających informacje dotyczące frekwencji słów polskiego języka mówionego jest to, że ze względu na ograniczone możliwości techniczne dane te są zbierane znacznie krócej niż dane dotyczące języka pisanego, a zatem zasób zgromadzonego w nich słownictwa jest mniejszy $[12,13]$. Dodatkowo zmieniające się tematy rozmów i chwilowe mody językowe udostępniane za pomocą mediów (filmów, urządzeń elektronicznych) mają znaczny wpływ na frekwencję poszczególnych słów i aby uczynić bazę nieczułą na tego typu trendy powinna być ona gromadzona systematycznie przez wiele lat i na możliwie szerokiej populacji osób zróżnicowanych wiekowo. Trzeba przecież pamiętać, że „Język mówiony, podobnie jak pisany nie jest jednolity stylistycznie i może przybierać różne formy zależnie od sytuacji, w jakiej został użyty - od polszczyzny wysokiej, jakiej używamy w sytuacjach oficjalnych, poprzez codzienne rozmowy po polszczyznę tzw. niską, rojącą się od wykrzykników i przekleństw" [14]. Tworząc listy słów na podstawie słownictwa $\mathrm{z}$ języka mówionego, należy podjąć decyzję, czy uwzględniać w nich słowa o wysokiej frekwencji w polszczyźnie potocznej, nacechowane silną ekspresywnością, ale mogące być postrzegane przez niektóre osoby badane jako niestosowne (np. słowo biust - w założeniu nienacechowane emocjonalnie, w opinii techników wykonujących audiometrię słowną jest słowem wywołującym u pacjentów emocje o różnym zabarwieniu). Zdaniem autorów niniejszej publikacji ze słownictwa stosowanego w teście należy wyeliminować nie tylko wszelkie naleciałości dialektalne, lecz także przekleństwa i słowa rubaszne oraz trudniejsze do zaakceptowania w sytuacji nienaturalnej, jaką jest badanie testowe.

\section{Parametry akustyczne list słownych}

Listy, które mają być prezentowane podczas badania, powinny być np. wyrównane pod względem stopnia trudności, tak by różne listy zaprezentowane $\mathrm{z}$ tym samym natężeniem temu samemu badanemu dawały takie same wyniki. Można to osiągnąć, uwzględniając różne czynniki, takie jak: długość słowa, umiejscowienie akcentu, struktura słowa. Klasyfikacje głosek polskich (artykulacyjna, akustyczna, audytywna i funkcjonalna) są szeroko opisywane w literaturze $\mathrm{z}$ zakresu fonetyki i fonologii [14-17]. Opracowując materiał do testu od strony akustycznej, warto mieć na względzie, że dla zrozumienia mowy polskiej najbardziej istotne są pasma o częstotliwości od $100 \mathrm{~Hz}$

\footnotetext{
1. Korpus IPI PAN - powstał w Instytucie Podstaw Informatyki PAN w latach 2001-2004. Zawiera ok. 250 mln słów, z czego język pisany stanowi 85\% (proza współczesna i dawna, teksty naukowe, prasa, ustawy), a język mówiony 15\% (stenogramy sejmowe i senackie).

Korpus PWN (wersja sieciowa) - 40 mln słów (segmentów). Język pisany - 95,5\% (prasa, książki beletrystyczne i niebeletrystyczne, druki ulotne i użytkowe, strony internetowe), język mówiony - 4,5\% (transkrypcja nagrań przypadkowych rozmów, programów telewizyjnych i audycji radiowych).

Korpus PELCRA (ang. Polish English Language Corpora for Research and Application): język pisany - 90\% (prasa, literatura i publikacje niebeletrystyczne, teksty prawnicze, rozprawy naukowe), język mówiony - 10\% (transkrypcja nagrań przypadkowych rozmów, przemówień publicznych, wywiadów, stenogramy przesłuchań).

Narodowy Korpus Języka Polskiego (NKJP) - w obrębie tego korpusu scalone zostały korpusy: IPI PAN, PWN i PELCRA, tworząc największy istniejący korpus języka polskiego. Prace nad rozbudową korpusu nadal trwają [13].
} 
do $2300 \mathrm{~Hz}$ lub od $500 \mathrm{~Hz}$ do $2000 \mathrm{~Hz}$, największy odsetek zrozumiałych słów języka polskiego mieści się w zakresie $1300-1600 \mathrm{~Hz}$, a język polski jest językiem nietonicznym (intonacja najczęściej nie zmienia znaczenia słowa, ale przekazuje stan emocjonalny mówcy) [6]. Literatura dotycząca przedmiotu przedstawia opisy akustyczne $\mathrm{z}$ wykorzystaniem różnych urządzeń i oprogramowania komputerowego. Przedstawione analizy akustyczne dotyczą nie tylko pojedynczych głosek [16-18], lecz także ich zespołów [19,20] oraz wymowy normatywnej [21-23]. Ze względu na indywidualne cechy każdego języka badania audiometrią słowną należy przeprowadzać w języku narodowym badanego, a materiał werbalny opracowuje się oddzielnie dla każdego języka [5,7,24,25].

Kolejnym istotnym czynnikiem wpływającym na wybór, czy dane słowo zostanie uwzględnione w projektowanym teście czy nie, powinna być długość słowa. Ludzki umysł, bazując na kompetencjach językowych, jest w stanie uzupełniać luki w słyszanym tekście, a im dłuższy wyraz, tym jest to łatwiejsze, gdyż więcej jest wskazówek umożliwiających prawidłowe uzupełnienie braków. To sprawia, że osoba niesłysząca lub niedosłysząca łatwiej zrozumie i powtórzy trzysylabowe słowo (np. samochód) niż bardzo często spotykane, ale jednosylabowe się, które w języku polskim nie jest używane samodzielnie.

Z długością słów wiąże się kwestia akcentu. Powszechnie wiadomo, że sylaba akcentowana stanowiąca „centrum energetyczne” słowa jest wypowiadana nieco głośniej i dłużej niż pozostałe sylaby, dzięki czemu jest łatwiej odbierana. W języku polskim akcent zazwyczaj pada na drugą sylabę od końca. Zatem aby uzyskać zrównoważone listy słów, do opracowywanego testu należy wybrać wyrazy, które sylabę akcentowaną mają w tym samym miejscu.

Z powyższego wynika, że spośród wszystkich słów zgromadzonych na listach frekwencyjnych w kręgu zainteresowania badaczy pozostaną jedynie słowa jednosylabowe lub dwusylabowe słowa spondejowe, nagrane w taki sposób, że obie sylaby są akcentowane. Wiadomo również, iż im dłuższe jest słowo, tym łatwiej słuchającemu uzupełnić ten fragment lub fragmenty słowa, które nie zostały prawidłowo usłyszane. To sprawia, że najtrudniejszymi, a zatem najlepszymi do zastosowania w badaniu są słowa jednosylabowe. Ich wykorzystanie umożliwi opracowanie krótkich list testowych o wysokiej wartości diagnostycznej w ocenie funkcjonalnej słuchu.

Język polski jest językiem spółgłoskowym, zawierającym znaczną liczbę grup spółgłoskowych, głosek
Wyrazy jednosylabowe:

\begin{tabular}{|c|c|}
\hline $\mathrm{V}$ & $o$ (co chodzi?), i (tak dalej) \\
\hline VC & on, as, ul, idź /itc/ \\
\hline $\mathrm{CV}$ & $t a, c z y / t \mathrm{ft} /$ \\
\hline CVC & nos, cień /'tsen/ \\
\hline $\mathrm{CCV}$ & kto, gdzie /'gdъe/ \\
\hline CCVC & sciek /'ctcek/ = śsieg, szczur /stfur/ \\
\hline CVCC & gość, pysk, żart, ząb/'zomp/ \\
\hline CCCVC & strup, splot \\
\hline CCCCVCC & pstrag /'pstronk/ \\
\hline
\end{tabular}

Wyrazy dwusylabowe:

$\begin{array}{ll}\text { VCV } & \text { oko, ile } \\ \text { VCCV } & \text { inny, obcy, Alpy } \\ \text { CVCV } & \text { kolo, picie /'pitbe/ } \\ \text { CCVCV } & \text { szczury/'Jtury/, ptaki, krata } \\ \text { CVCCV } & \text { bomba, taczki /'tat'ci/ } \\ \text { CCVCCV } & \text { plaba/'plomba/, krótki } \\ \text { CCCVCCV } & \text { zgrabny }\end{array}$

Rycina 1. Wybrane typy struktur wyrazowych [28] Figure 1. Chosen types of word structures [28]

dentalizowanych. Należy zatem zwrócić uwagę na strukturę poszczególnych sylab i częstość występowania grup spółgłoskowych w obrębie materiałów zgromadzonych na listach frekwencyjnych Narodowego Korpusu Języka Polskiego i możliwie najdokładniej odzwierciedlić to w przygotowywanym teście [20,26,27]. Przy opracowywaniu list trzeba uwzględnić nie tylko częstość występowania sylaby o pewnej strukturze, np. CV, CCV (ang. consonant - spółgłoska, vowel - samogłoska), w wyrazach, ale też pomnożyć ten wynik przez częstość użycia słowa, w jakim sylaba o tej strukturze wystąpiła. Dopiero taka analiza frekwencji umożliwi wyłonienie struktur, które po uwzględnieniu częstości występowania poszczególnych głosek w języku polskim pozwoli na skonstruowanie w pełni zrównoważonych list słownych [19] (rycina 1).

Opracowanie testu, w którym bodźcem będą słowa, wymaga zainteresowania się frekwencją głosek, tak by częstość ich występowania w badaniu była maksymalnie zbliżona do ich frekwencji w polszczyźnie [28-30]. Mimo że część badaczy powołuje się na badania wskazujące, że równoważenie fonetyczne audiometrii słownej nie ma wpływu na wynik uzyskiwany przez pacjenta [31], to jednak norma PN-EN ISO 8253-3: 2012(E) wskazuje na konieczność zwrócenia uwagi na fonetyczne wyrównanie poszczególnych list [23-25] (rycina 2) ${ }^{2}$.

\section{$\begin{array}{llllllllllllllllllllllllll}\text { e } & a & 0 & t & j & n & i & m & i & v & p & r & u & s & k & j & d & l & \int & w & 6 & z\end{array}$ $\begin{array}{llllllllllllllllllllll}105 & 96 & 85 & 47 & 43 & 40 & 38 & 35 & 34 & 32 & 30 & 29 & 28 & 28 & 25 & 24 & 21 & 19 & 19 & 18 & 16 & 15\end{array}$

 $\begin{array}{llllllllllllllll}15 & 13 & 13 & 13 & 12 & 12 & 12 & 10 & 8 & 7 & 7 & 2 & 2 & 1 & 0\end{array}$}

Rycina 2. Średnia częstość występowania polskich fonemów (powyższe liczby określają krotność występowania na 1000 bieżących fonemów) [28]

Figure 2. Average incidence of Polish phonemes (the numbers show times of incidence per 1000 phonemes) [28]

2. Różnice w zapisie głosek na rycinie 1 i rycinie 2 wynikają z zastosowania różnych alfabetów fonetycznych. 
Należy też uwzględnić zjawiska fonetyczne powstające pomiędzy głoskami na skutek płynnego przechodzenia mięśni fonacyjno-artykulacyjnych z jednego układu w drugi (tzw. koartykulacje), dzięki którym zachodzą różne zjawiska, m.in. ubezdźwięczniania (np. słowo wszyscy jest wymawiane z głoską /f/ na początku, a w słowie herb na końcu wyrazu w polszczyźnie ogólnej wymawia się /p/), denazalizacji (np. słowo wątły wymawiane jest przez /on/), ściągnięcia grup głosek (np. wyraz jabłko jest wymawiany jako /japko/) [19]. Procesy te są najczęściej nieuświadamiane, jednak modyfikują formanty i energię głosek oraz sylab, co może mieć wpływ na łatwość rozumienia.

Czynnikami wpływającymi na odbiór danego słowa są częstotliwość głosek składowych oraz ich energia. Praktyka kliniczna wskazuje, że osoby o różnych typach niedosłuchu mają trudności z różnymi głoskami. Osoby z niedosłuchem w zakresie wysokich częstotliwości mają kłopot z odbiorem słów, w których występuje duża liczba głosek syczących i szeleszczących, takich jak $/ s /, / z /, / s z /, / f /, / c h /$, zwłaszcza jeśli są one bezdźwięczne (pozbawione tonu krtaniowego, który znajduje się na niższych częstotliwościach niż inne formanty głoski). Dla takich osób słowa szef, chrzest są trudne. Jeśli dodatkowo te głoski znajdują się w wygłosie wyrazu, wówczas mają mniejszą energię, a przez to stają się trudniejsze do wyodrębnienia i odróżnienia słuchowo. Z kolei osoby $\mathrm{z}$ niedosłuchem w zakresie niskich częstotliwości mogą mieć trudności z odbiorem słów, w których znaczną część stanowią głoski niskie, $\mathrm{np} . / \mathrm{m} /, \mathrm{n} / \mathrm{/} / \mathrm{\ell} /$. Tym osobom mogą sprawiać kłopoty słowa takie jak mut, tłum.

Po opracowaniu i nagraniu materiału werbalnego dokonuje się jego walidacji, sprawdza się wyrównanie stopnia trudności dla poszczególnych list. Dokonuje się tego na podstawie badania wykonywanego z udziałem osób otolaryngologicznie zdrowych, prawidłowo słyszących, a materiał testowy prezentuje się w takich warunkach, w jakich test ma być używany w praktyce klinicznej (z maskowaniem bądź w ciszy).

\section{Czynniki zależne od osoby badanej}

Przy opracowywaniu list słownych należy też uwzględnić pewne czynniki zależne od samego pacjenta, takie jak narodowość, wiek, inteligencja, wykształcenie, sprawność językowa rozumiana jako umiejętność swobodnego posługiwania się systemem języka polskiego adekwatnie do sytuacji, tematu i odbiorcy [32]. Osobie o wyższym wykształceniu, większym obyciu w języku, wyższym ilorazie inteligencji znacznie łatwiej będzie powtórzyć słowa rzadko występujące $\mathrm{w}$ języku, ponieważ w procesie edukacji osoba taka „osłuchała się" z tego typu słowami. W znacznej części opracowanych w Polsce testów audiometrii słownej wykorzystywano listy słów i głosek stworzone wyłącznie na podstawie tekstów pisanych [33-35]. Czerpanie materiału werbalnego ze źródeł tego typu może sprawiać, że osoby, których zasób słów jest z różnych powodów uboższy, mogą mieć mniejsze szanse na wykonanie testu zgodnie ze swoim potencjałem słuchowym. Ze względu na możliwości techniczne i dostępność źródeł testy audiometrii słownej przeznaczone dla dzieci zazwyczaj opierały się na tekstach zawartych w podręcznikach lub literaturze dziecięcej, a zatem nietworzone przez dzieci, ale pisane dla nich przez dorosłych [34,35]. Można więc wnioskować, że słownictwo w nich zawarte nie było słownictwem typowo dziecięcym.

Aby wyrównać szanse osób badanych, uniezależnić je od doświadczeń edukacyjnych, warto rozważyć zastosowanie w teście słów „sztucznych”, pozbawionych znaczenia, zwłaszcza jeśli celem badania jest ocena dyskryminacji dźwięków mowy. Wówczas osoba poddawana badaniu może oprzeć się jedynie na swoich umiejętnościach słuchowych, bez możliwości odwołania się do słownika zgromadzonego w umyśle.

Ludzie o wysokiej inteligencji mają również zdolność szybkiego uczenia się, co może wpłynąć na ich wynik uzyskany podczas badania, jeśli dana lista testowa jest prezentowana pacjentowi nie po raz pierwszy. Można próbować uniknąć tego efektu albo opracowując wiele zrównoważonych list słów i dbając, by przy kolejnych badaniach listy prezentowane pacjentowi nie powtarzały się, albo nagrywając mniejszą liczbę list, ale w taki sposób, by słowa w obrębie listy były prezentowane pacjentowi w sposób zrandomizowany (za każdym razem inna kolejność słów w obrębie danej listy).

Czynnikiem najsilniej wpływającym na długość badania jest to, dla jakiej grupy wiekowej pacjentów będzie przeznaczone opracowywane narzędzie. Chodzi tu nie tylko o podatność na zmęczenie u dzieci i umiejętność dłuższego utrzymania uwagi na zadaniu u osób dorosłych, które wpłyną na długość list słów i na długość badania jako całości. Istotny jest bowiem dobór słów, które miałyby się znaleźć w teście, ponieważ słownik dziecięcy znacząco różni się od słownika dorosłych [36-39].

Przy badaniu osób w różnym wieku, zwłaszcza dzieci, należy uwzględnić także ich różne możliwości artykulacyjne, np. mogą nie potrafić wymawiać niektórych głosek bądź je zniekształcać $[40,41]$. Ma to znaczący wpływ na osiągany wynik w sytuacji, gdy oceniamy, czy dane słowo jako całość zostało powtórzone prawidłowo czy też nie. Rozwiązaniem, które mogłoby prowadzić do większej precyzji i wyższej rzetelności zapisywanego wyniku, byłoby zastosowanie oceny, czy dany fonem został powtórzony dokładnie tak jak we wzorcu. Byłoby to istotne, zwłaszcza jeśli celem opracowywanej audiometrii słownej miałaby być ocena dyskryminacji dźwięków mowy.

Po wybraniu materiału słownego należy starannie wybierać lektora, który miałby przeczytać listy słów do nagrania. Ze zrozumiałych względów należy wybrać osobę o przyjemnym do słuchania głosie, posługującą się językiem polskim pozbawionym jakichkolwiek naleciałości dialektalnych oraz wad wymowy. Lektor powinien czytać listy tych słów $\mathrm{z}$ jednakowym natężeniem głosu, w umiarkowanym tempie, unikając nadawania im linii intonacyjnej czy przerysowywania artykulacji, np. wymowy doliterowej wyrazów kończących się literami $b, d, w$, które w wygłosie wyrazów powinny być wymawiane jako $/ p /, / t /, / f /$. Oznacza to, że słowa o zapisie: brąz, dźwig powinny być wypowiedziane przez lektora jako /brąs/, /dźwik/. Ze względu na różnice w głosie męskim i kobiecym wskazane jest, aby lektorami byli zarówno mężczyzna, jak i kobieta. Gdy słowa czytane są badanemu „na żywo”, nie sposób uniknąć różnic 
przy podawaniu słów testowych. Znacznie korzystniejsze jest odtwarzanie nagrań profesjonalnych lektorów, by wyniki badań osób z podobnym niedosłuchem, wykonywane w różnych dniach mogły być porównywane. Podczas prowadzenia badań typu life voice wykonywanych w różnych dniach, wynikających czy to ze stanu psychofizycznego technika (badacza), presji czasu czy innych czynników, może dochodzić do różnych zniekształceń (np. tempa, barwy głosu). Podczas nagrywania należy zadbać o to, by $\mathrm{w}$ pomieszczeniu, w którym trwa nagranie, nie było pogłosu, najlepiej zaś, by była to specjalna, wygłuszona kabina. Ze względu na to, że urządzenia służące do nagrywania mogą generować zakłócenia i szum, trzeba zadbać, by nagranie odbywało się z wykorzystaniem urządzeń wysokiej klasy, w postaci zapisu cyfrowego, aby jakość nagrania z czasem nie ulegała obniżeniu. Warto przy tym wybrać format pliku zachowujący jakość nagrania a jednocześnie popularny, by jego odtwarzanie w różnie wyposażonych ośrodkach nie nastręczało trudności.

Przy opracowywaniu testu warto rozważyć, w jakich warunkach i w jaki sposób będzie używany. Czy audiometria słowna, która jest opracowywana, będzie służyła w przyszłości do badań przesiewowych czy też do badań klinicznych, w jakich warunkach będzie wykonywana. Czy materiał werbalny będzie podawany przez słuchawki, w wolnym polu czy przez wibrator kostny, czy badanie będzie wykonywane obuusznie czy dla każdego ucha oddzielnie.

Oceniając opracowywany test, uwzględnia się błąd pomiaru. Norma ISO 8253-3: 2012 (E) określa czynniki, które mogą wpływać na pomiar. Należą do nich:

a) możliwości użytego sprzętu audiometrycznego,

b) typy użytych przetworników i ich dopasowanie przez badającego,

c) użyty materiał werbalny,

d) procedura przeprowadzania testu,

e) warunki, w których przeprowadzany jest test, w szczególności zaś hałas otoczenia,

f) kwalifikacje i doświadczenie osoby wykonującej badanie,

g) jakość współpracy osoby badanej i wiarygodność jej odpowiedzi,

h) użycie maskowania szumem, który nie był wcześniej zoptymalizowany.

Wraz z błędem pomiaru należy określić współczynnik ufności. Obecnie obowiązująca norma ISO dopuszcza badania, które charakteryzują się 95\% współczynnikiem ufności. Uznaje się listy za wyrównane, jeśli wyniki badań uzyskane dla poszczególnych list pokrywają się między sobą z 95\% przedziałem ufności.

\section{Walidacja}

Aby określić wartość kliniczną opracowanego narzędzia, konieczna jest jego walidacja. Ścieżka walidacyjna możliwa do zastosowania podczas oceny większości metod pomiarowych jest w statystyce przedstawiana następująco:

1. Przygotowanie doświadczenia i zgromadzenie danych.

2. Czyszczenie danych i wstępna analiza opisowa.

3. Badanie rozkładu i weryfikacja podstawowych założeń.

4. Ocena dokładności.

5. Ocena stabilności.
W niniejszej pracy autorzy skupili się na pierwszym punkcie przedstawionej powyżej ścieżki walidacyjnej. Norma PN-EN ISO 8253-3: 2012(E) określa minimalną liczebność grupy badanej na 10 osób, zaleca jednak wykonywanie tej oceny na liczniejszych grupach, zwłaszcza jeśli wyniki badania wykazują się dużą zmiennością (np. w przypadku dzieci są to grupy mające po minimum 25 osób).

Zgromadzone dane poddawane są analizie. Sprawdza się rozkład uzyskanych wyników w obrębie badanej grupy. Usuwane są błędy i wartości nietypowe, odstające od zbioru. Ocena dokładności musi uwzględniać opisaną wcześniej poprawność i precyzję wykonania pomiarów, a także uwzględnić zmienność pod wpływem różnych czynników, które mogły zaistnieć podczas ich dokonywania. Na tym etapie sprawdza się takie czynniki jak powtarzalność (czy istnieją różnice pomiędzy kolejnymi pomiarami) i odtwarzalność (tj. jakie są różnice w pomiarach pomiędzy poszczególnymi osobami prowadzącymi badanie). Ocena stabilności testu w czasie (tu: audiometrii słownej) dokonywana jest w statystyce za pomocą tzw. kart kontrolnych [42].

Opracowany test powinien się charakteryzować następującymi cechami:

1. Rzetelność (test jest rzetelny, gdy daje dużą dokładność wyników):

- powtarzalność (otrzymywanie takich samych wyników przez tego samego badacza przy powtarzaniu badania),

- odtwarzalność (otrzymywanie takich samych wyników w tej samej populacji przez różnych badaczy).

2. Trafność - zdolność testu do mierzenia danej cechy w taki sposób, że wartość uzyskana z pomiaru jest zgodna z wartością rzeczywistą. Miarą trafności są:

- czułość - proporcja osób naprawdę chorych w badanej populacji, które zostały również przez test zakwalifikowane jako chore,

- swoistość - proporcja osób naprawdę zdrowych w badanej populacji, które zostały również przez test zakwalifikowane jako zdrowe.

3. Wartość predyktywna dodatnia - przewidywana częstość choroby u osób z wynikiem dodatnim.

4. Wartość predyktywna ujemna - przewidywana częstość wykluczenia choroby u osób z wynikiem ujemnym.

5. Wskaźnik Youdena - sumaryczny wskaźnik trafności testu.

Po przeprowadzeniu badań na większej i bardziej zróżnicowanej grupie badanych oraz analizie statystycznej otrzymanych wyników można określić, czy nowe narzędzie jest przydatne i może być stosowane w praktyce klinicznej [43].

\section{Wnioski}

Wymagania wobec audiometrii słownej są bardzo wysokie. W praktyce klinicznej poszukiwane są uniwersalne narzędzia badawcze, które mogą być wykorzystywane do różnych celów, na dużych grupach badanych (dorośli, dzieci), których przeprowadzenie zajmuje niewiele czasu, listy słów są możliwie jak najkrótsze, a wyniki są rzetelne i korelujące $\mathrm{z}$ wynikami innych testów oceniających ten sam deficyt. Pomimo wielu wysiłków do tej pory nie udało się opracować jednego, uniwersalnego narzędzia spełniającego wszystkie wymienione w niniejszej pracy 
kryteria $[1,4,10,44,45]$. W Instytucie Fizjologii i Patologii Słuchu prowadzone są prace nad przygotowaniem list słów, które pozwolą zidentyfikować potencjał percepcyjny badanej osoby, a to, których głosek bądź ich zespołów nie wysłuchuje, będzie wskaźnikiem jej ograniczeń w dyskryminacji ciągu fonicznego.
Publikacja powstała $w$ zwiazku $z$ realizacja projektu pn. „Zintegrowanysystem narzędzi do diagnostyki i telerehabilitacji schorzeń narząów zmysłów (słuchu, wzroku, mowy, równowagi, smaku, powonienia)" INNOSENSE, wspótfinansowanego przez Narodowe Centrum Badań i Rozwoju w ramach Programu STRATEGMED.

\section{Piśmiennictwo:}

1. Nissen SL, Harris RW, Jennings L-J, Eggett DL, Buck H. Psychometrically equivalent mandarin bisyllabic speech discrimination materials spoken by male and female talkers: Materiales de discriminación del lenguaje con bisilábicos en Madarín psicométricamente equivalentes utilizados por hablantes del sexo masculino y femenino. Int J Audiol, 2005; 44(7): 379-90.

2. Podstawy audiometrii mowy. W: Zarys audiologii klinicznej. Poznań: Wydawnictwa Akademii Medycznej im. Karola Marcinkowskiego; 2000, s. 232-35.

3. Pruszewicz A, Wiskirska-Woźnica B. Przydatność audiometrii mowy w diagnostyce zaburzeń słuchu. W: Obrębowski A, red. Wybrane zagadnienia z audiometrii mowy. Poznań: Wydawnictwo Naukowe Uniwerystetu Medycznego im. Karola Marcinkowskiego w Poznaniu; 2011, s. 110-16.

4. Brandy WT. Speech audiometry. Handb Clin Audiol, 2002; 5: 96-110.

5. Wang S, Mannell R, Newall P, Zhang H, Han D. Development and evaluation of Mandarin disyllabic materials for speech audiometry in China. Int J Audiol, 2007; 46(12): 719-31.

6. Skrodzka E. Audiometria mowy. W: Hojan E, red. Protetyka Słuchu Akustyka. Poznań: Wydawnictwo Naukowe UAM; 2014, s. 275-308

7. Han D, Wang S, Zhang H, Chen J, Jiang W, Mannell R i wsp. Development of Mandarin monosyllabic speech test materials in China. Int J Audiol, 2009; 48(5): 300-11.

8. Egan JJ. Basic aspects of speech audiometry. Ear Nose Throat J, 1979; 58(5): 190.

9. Demenko G, Pruszewicz A. Testy lingwistyczne. W: Pruszewicz A, red. Zarys audiologii klinicznej. Poznań: Wydawnictwa Akademii Medycznej im. Karola Marcinkowskiego w Poznaniu; 2000, s. 245-54

10. Piłka E. Testy słowne dostępne i wykorzystywane w Polsce w audiometrii mowy - rys historyczny. Now Audiofonol, 2015; 4(4): 67-74.

11. Pruszewicz A, Surmanowicz-Demenko G, Jastrzębska M. Polskie testy do badania audiometrią mowy. W: Obrębowski A, red. Wybrane zagadnienia z audiometrii mowy. Poznań: Wydawnictwo Naukowe Uniwerystetu Medycznego im. Karola Marcinkowskiego; 2011.

12. Pęzik P. Język mówiony w NKJP. Nar Korpus Języka Pol, 2012: $37-47$.

13. Korpusy języka polskiego, korpusy.net, dostęp: 22.01 .2016

14. Rocławski B. System fonostatystyczny współczesnego języka polskiego. Gdańsk: Ossolineum, 1981.

15. Rocławski B. Zarys fonologii, fonetyki, fonotaktyki i fonostatystyki współczesnego języka polskiego. Gdańsk: Uniwersytet Gdański, 1976.

16. Wierzchowska B. Wymowa polska. Państwowe Zakłady Wydawnictw Szkolnych, 1971

17. Jassem W. Podstawy fonetyki akustycznej. Warszawa: PWN, 1973.

18. Wierzchowska B. Struktura akustyczna dźwięków języka polskiego. Logopedia, 1976; 7: 88-104.
19. Śledziński D. Fonemy, difony, trifony i sylaby - charakterystyka jednostek na podstawie korpusu tekstowego. Kwartalnik Językoznawczy, 2010; 3-4(3-4): 84-112.

20. Śledziński D. Fonetyczno-akustyczna analiza struktury sylaby w języku polskim na potrzeby technologii mowy. Unpubl PhD Thesis Adam Mickiewicz Univ Pozn Pol, 2007.

21. Trochymiuk A. Wymowa dzieci niesłyszących. Analiza akustyczna i audytywna. Lublin: Uniwersytet Marii Curie-Skłodowskiej, 2008.

22. Lorenc A. Zaburzenia dźwięczności Analiza akustyczna i audytywna. Logopedia, 2012; 41: 71-107.

23. Waryszak MU, Kurkowski ZM. Ocena akustyczna artykulacji głosek. Now Audiofonol, 2015; 4(4): 28-35.

24. Da Costa EA. Brazilian Portugese speech material and its application in occupational audiology. Audiology, 2001; (40): $123-32$.

25. Määttä TK, Sorri MJ, Huttunen KH, Välimaa TT, Muhli AA. On the construction of a Finnish audiometric sentence test. Scand Audiol, 2001; 30(1): 171-73.

26. Śledziński D. Analiza struktury grup spółgłoskowych w nagłosie oraz w wygłosie wyrazów w języku polskim. Kwart Językoznawczy, 2010; (3-4): 61-83.

27. Dziubalska-Kołaczyk K, Jankowski M, Wierzchoń P. Classification of the lexicon of modern Polish according to the structure of consonant clusters. 2011.

28. Łobacz P, Jassem W. Fonetyka akustyczna w audiologii. W: Pruszewicz A, red. Zarys audiologii klinicznej. Poznań: Wydawnictwa Akademii Medycznej im. Karola Marcinkowskiego; 2000, s. 88-106.

29. Ziółko B, Gałka J, Ziółko M. Polish phoneme statistics obtained on large set of written texts. Comput Sci, 2009; 10: 97-106.

30. Steffen M. Częstość występowania głosek polskich. Biul Pol Tow Językoznawczego, 1957; 16: 145-64.

31. Martin FN, Champlin CA, Perez DD. The question of phonetic balance in word recognition testing. J Am Acad Audiol, 2000; 11(9): 509-13.

32. Markowski A. Kultura języka polskiego: Teoria. Zagadnienia leksykalne. Wydawnictwo Naukowe PWN, 2005.

33. Taniewski J, Kugler R, Wysocki Z. Audiometria słowna mową polska. Otolaryngol Pol, 1961; 15: 131.

34. Iwankiewicz S. Audiometria mowy wieku dziecięcego. Otolaryngol Pol, 1963; 17(4).

35. Kugler R. Audiometria słowna u dzieci. Otolaryngol Pol, 1964; 18(2): 235-41.

36. Zgółlkowa H, Bułczyńska K. Słownictwo dzieci w wieku przedszkolnym: listy frekwencyjne. Poznań: Wydawn. Nauk. Uniwersytetu im. Adama Mickiewicza w Poznaniu, 1987.

37. Porayski-Pomsta J. Umiejętności komunikacyjne dzieci w wieku przedszkolnym: studium psycholingwistyczne. Warszawa: Wydawnictwa Uniwersytetu Warszawskiego, 1994.

38. Piłat J. Słownik umysłowy dzieci siedmioletnich za środowiska miejskiego i wiejskiego na przykładzie pola tematycznego „zwyczaje i obyczaje”. Porad Językowy, 2006; (08): 27-42. 
39. Smoczyńska M, Krajewski G, Łuniewska M, Haman E, Bulkowski K, Kochańska M. Inwentarze rozwoju mowy i komunikacji (IRMIK). „Słowa i gesty”, „Słowa i zdania”. Podręcznik. Warszawa: Instytut Badań Edukacyjnych, 2015.

40. Krajna E. Rozwojowa norma fonetyczna - oczekiwania i fakty. Logopeda, 2005; 1(1): 33-46.

41. Milewski S. Grupy spółgłoskowe w języku mówionym dzieci przedszkolnych. Logopeda, 2005; 1(1): 5-32.

42. Walidacja metod, www.statsoft.pl, dostęp: 20.07.2016.
43. Gierek T, Gwóźdź-Jezierska M, Ślaska-Kaspera A. Ocena skuteczności testu przesiewowego „Słyszę" na podstawie wyników badań skryningowych słuchu u dzieci na Śląsku w 2002 roku. Otolaryngol Pol, 2007; 61(5): 707-12.

44. Mackie KC, Dermody PJ. Word Intelligibility Tests in Audiology for the Assessment of Communication Adequacy. Australian Government Publishing Service, 1982.

45. Świdziński P, Wiskirska-Woźnica B, Pruszewicz A. Metodologia jakościowych i ilościowych badań słuchu mową. W: Obrębowski A, red. Wybrane zagadnienia $\mathrm{z}$ audiometrii mowy; 2011, s. 56-68. 